\title{
БАНКОВСКИЙ НАДЗОР В РФ НА СОВРЕМЕННОМ ЭТАПЕ: ПРОБЛЕМЫ ДЕЙСТВУЮЩЕЙ СИСТЕМЫ
}

\author{
(c) 2020 Казанкова Татьяна Николаевна \\ кандидат педагогических наук, доцент \\ Самарский государственный экономический университет, Россия, Самара \\ E-mail: tatianaok78@yandex.ru \\ (c) 2020 Ефремова Екатерина Сергеевна \\ магистрант \\ Самарский государственный экономический университет, Россия, Самара \\ E-mail: yakovleva_kate@inbox.ru \\ (c) 2020 Пустовалова Елизавета Николаевна \\ магистрант \\ Самарский государственный экономический университет, Россия, Самара \\ E-mail: eliz.mois27@gmail.com
}

В статью включено описание направлений и форм банковского надзора, осуществляемого ЦБ РФ, рассматривается специфика его реализации. Обращается особое внимание на расширение полномочий Банка России в связи с внедрением международных стандартов, выработанных Базельским комитетом по банковскому надзору. Проведён анализ изменений в системе финансового и банковского надзора, а также выделены основные проблемы, связанные с указанной системой.

Ключевые слова: банковский надзор, банковский контроль, Центральный банк Российской Федерации, кредитная организация, банковский сектор, стандарты Базеля, банк, финансовая организация.

В нынешней действительности специфический экономический и социальный характер кредитных организаций представляет собой фактор, оказывающий влияние на необходимость в контроле над банковским сектором, что крайне важно для модернизации российской экономики в целом. Российская Федерация выступает в качестве такой страны, в которой основополагающими функциями контроля и надзора за работой банковских организаций наделен Банк России. Интеграция экономик различных стран вносит изменения в существующий механизм банковского управления, равным образом, порождая потребность к непрерывному приспособлению к переменам и условиям всемирного банковского объединения. Кроме того, в том случае если в российской экономике преобразования, служащие причиной больших реформ в отношениях между субъектами регулирования, оказываются на недопустимой законодательной базе, тогда непосредственно такие преобразования являются поводом усиления разногласий как в механизме образования структуры власти, так и в подсистеме банковского надзора.

Стоит отметить, особую значимость выбранной темы исследования в настоящий момент, поскольку сложившееся неустойчивое положение становления и упадка экономики негативно сказались на поддержании эффективности банковского надзора.

Необходимо начать с того, что на данном этапе развития банковского надзора в России различают две ключевые его стороны: инспекционное функционирование и дистанционный надзор Центрального банка Российской Федерации. Дистанционный надзор позволяет изучить функционирование кредитных организаций при помощи рассмотрения переданных отчетных документов. Вместе с тем, исходная отчетность может иметь недостоверные сведения, что приводит к нерезультативному надзору. Ведь только в процессе инвестиционных проверок высока вероятность обнаружения ошибок в отчетных документах [6].

Тем самым следует отметить преимущества инвестиционных проверок, включающие всю область деятельности кредитной организации, которые предоставляют возможность собрать надлежащую оценку степени стабильности, финансового положения и дальнейших возможностей банка.

Стоит обратить внимание, что в теории су- 
ществует три формы реализации банковского надзора: предварительный, текущий и последующий. Причем достоинство данного разграничения заключается в том, что оно содействует результативности и постоянству контрольнонадзорной деятельности Центрального банка Российской Федерации.

Банк России производит предварительный банковский надзор на стадии регистрации и лицензирования функционирования банка. Необходимо подчеркнуть, что основополагающей задачей данного надзора выступает анализ репутационного и финансового состояния не только учредителей кредитной организации, но и переданных ими документов. Следовательно, только в случае удовлетворительного финансового состояния и деловой репутации учредителей банка, непротиворечивости документов требованиям законодательства, Центральный банк Российской Федерации принимает решение, на основании которого вносится запись в единый государственный реестр юридических лиц и информируется об этом действии Банк России.

При этом завершенной предварительная стадия банковского надзора будет признаваться тогда, когда учредители уставного капитала кредитной организации совершат $100 \%$ оплату и приобретут лицензию на выполнение банковских операций.

Что же касается текущего надзора, то стоит сказать, что он производится на протяжении всего функционирования банка по таким сторонам: контроль за выполнением кредитными организациями текущего законодательства, правовых актов Банка России и пруденциальный контроль. Следует заметить, что в процессе пруденциального контроля Центральный банк Российской Федерации анализирует деятельность банка, делая акцент на исполнение нормативов, установленных Банком России; получение в определенный срок заключения аудитора, а также отчетных сведений и их обнародование в СМИ.

Нельзя не упомянуть и последующий бан- ковский надзор, осуществляемый относительно нестабильных кредитных организаций, а также банков, у которых Центральный банк Российской Федерации приостановил действие или отозвал лицензии на совершение банковских операций. Такая форма надзора заключается в анализировании Банком России и резюмировании отчетности кредитных организаций.

Стоит выделить также и тот факт, что Центральный банк Российской Федерации периодически осуществляет множество различных действий, ориентированных на улучшение банковского надзора, которые позитивно сказываются и на всей деятельности банковской системы. Необходимо подчеркнуть, что в целом система банковского надзора функционирует достаточно продуктивно (табл. 1) [3].

Следует обратить особое внимание, что функциями по законодательному регламентированию, контролю и надзору за работой банков в полном объеме Банк России наделен лишь в 2013 году, приобретя положение мегарегулятора на российском финансовом рынке. В то же время значимая часть юридических норм взята из зарубежного банковского права, утвержденных Банком международных расчетов. Причем в его составе находятся Базельский комитет по банковскому контролю и Совет финансовой стабильности, на которых возложены полномочия по формированию результативных техник реализации контроля за стабильностью государственно важных кредитных и страховых организаций, а также механизма вычисления своих накоплений и требуемых показателей [1].

Стоит подчеркнуть, что Центральный банк Российской Федерации не остается в стороне и динамично сотрудничает с вышеуказанными органами, постепенно внося определенные изменения в правовую систему Российской Федерации основополагающими пунктами договоров Базеля I (1970-1980 г.г.), Базеля II (2004 г.), Базеля III (2010 г.). Необходимо упомянуть, что последнее соглашение утверждено было после известного этапа всемирного финансового

Таблица 1. Динамика отзыва лицензий на осуществление банковских операций у кредитных организаций за 2016-2019 г.г.

\begin{tabular}{|c|c|}
\hline Год & Количество кредитных организаций \\
\hline 2016 & 97 \\
\hline 2017 & 51 \\
\hline 2018 & 60 \\
\hline 2019 & 24 \\
\hline
\end{tabular}


упадка 2007-2009 г.г., тем самым его условия ориентированы непосредственно на установление полной совокупности мероприятий по обеспечению надежности банковского сектора, увеличение величины уставного капитала банков, внедряются факультативные правила к ликвидности активов и образование резервных запасов в случае возникновения очередных экономических подрывов. Как известно, уже с 1 января 2019 года полностью действуют положения Базеля III, что увеличивает полномочия и эффективно сказывается на надзоре Банком России за функционированием всех кредитных организаций.

Однако, в банковской сфере существует мнение, что реализованные стандарты Базеля III не решают множества проблем, которые возможно устранить при помощи введения Базеля IV. Следует заметить, что такое внесение изменений в стандарты банковской деятельности вызовет задействование дополнительных средств, наряду с этим имеется большая вероятность, что реальность не оправдает ожидания. Следование требованиям Базеля IV сократит способности кредитных организаций к повышению кредитования, что соответственно неблагоприятно отразится на экономике страны. По всей видимости, при выполнении данных стандартов станут оставлять рыночную экономику некрупные банки и будет отмечаться отсутствие конкуренции.

Следует отметить, что весьма важным фактором является сокращение административных обязанностей на работу банковских организаций. В настоящее время согласно закону о защите конкуренции при приобретении акций нет необходимости в координировании сделок, а именно по статье 28 ФЗ «О защите конкуренции» предварительное согласование ФАС требуется только в следующих случаях:

- приобретение блокирующего пакета, что составляет $25 \%$ акций;

- приобретение контрольного пакета, что составляет 50\% акций;

- приобретение пакета, который исключает блокировку другими лицами вердиктов акционера, что составляет 75\% акций.

Можно выделить первую проблему по работе надзорных органов ЦБ РФ - формирование самим Центробанком «административных преград» для членов финансового рынка, что создает проблемы для участников самого рынка. Следовательно, необходимо разрешать вопрос о том, насколько система контрольных органов и их полномочий ЦБ РФ является эффективной.

Также, к одной из важных проблем, которая возникает при проведении контрольнонадзорных мероприятий ЦБ РФ, есть проблема большого числа финансовых организаций на рынке. К примеру, в настоящее время число зарегистрированных различных финансовых организаций и лиц по различным финансовым направлениям составляет более 10 тысяч, в число которых входят всевозможные финансовые направления, такие как страховые услуги, кредитные организации, ломбарды и др. Сложность возникает и в количестве участников финансового рынка, и в количестве различных финансовых направлений, т.е. необходим индивидуальный подход в контрольнонадзорных мероприятиях органов ЦБ РФ для каждой группы участников.

Следующая проблема - нормы, которые ЦБ РФ публикует в рамках рекомендательных писем. Они не являются нормативными актами и не обязательны к исполнению для банковских организаций. Однако, основываясь на практическом применении, рекомендательные письма Банка России становятся в обязательные к исполнению, но контроль за исполнением лежит только на самой кредитной организации, а не Центробанком.

В настоящий момент значительному контролю подвергаются именно банковские организации, это объясняется индивидуальностью банковской деятельности. В усиленном контроле банковских организаций со стороны ЦБ РФ есть и положительные стороны - на рынке банковских услуг условия работы улучшаются, создаются преграды при попытках организации незаконной банковской деятельности, но также есть и отрицательные стороны. Одним из значительных последствий является то, что при усиленном контроле работы банковских организаций отсутствует положительная динамика по включению в банковскую деятельность новых кредитных организаций, конкуренция снижается. На рисунке 1 приведена статистика за последние 10 лет по количеству банков на территории Российской Федерации, число банков определено на 1 января каждого года (рис. 1) [4].

Усиленный контроль за деятельностью кредитных организаций в первую очередь связан с тем, что существует проблема отчётности банковских организаций. Специалисты отмечают, что в настоящее время существует излишнее количество форм отчётности банковских органи- 


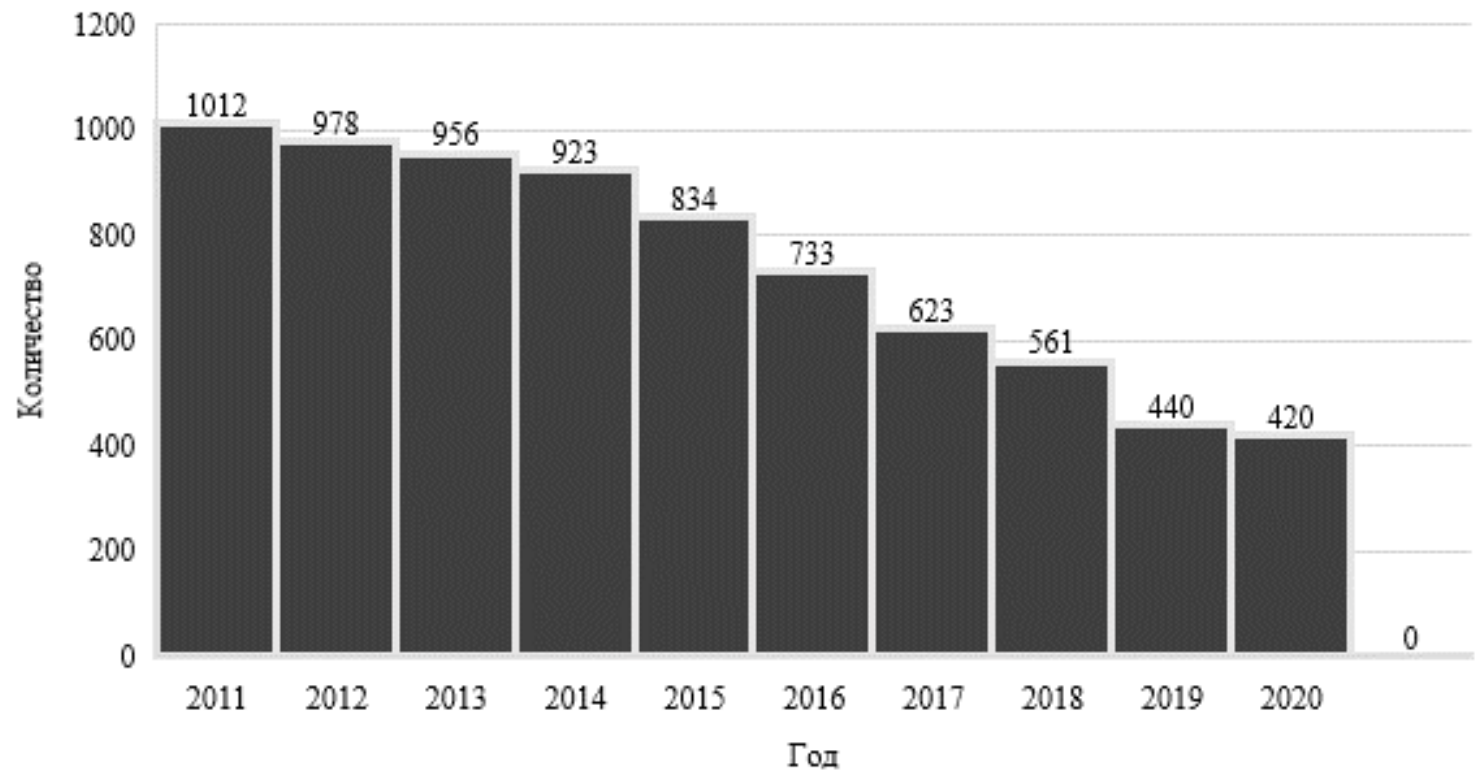

Рисунок 1. Количество банков в России

заций, которые зачастую либо не представляют собой предмет для проведения контрольных мероприятий, либо документы повторяют суть друг друга. Специалистами было подсчитано, что для работы над отчётными документами кредитная организация тратит около 15\% от всего рабочего времени организации. Центральный банк ежегодно от каждой кредитной организации получает около 4 тысяч отчётов, представленных в более чем 80 различных формах. Помимо ЦБ РФ кредитные организации также отправляют отчётные документы в прочие органы государственной власти. Исходя из этого, можно сказать, что кредитные организации самостоятельно проводят надзор своей деятельности, который занимает значительную часть времени и затрачивает финансовые и рабочие ресурсы [5].

Отдельное внимание следует уделить ликвидации банковских организаций. Начиная со второй половины 90-х годов значительная часть кредитных организаций находились в процессе процедуры ликвидации, данный факт не устраивал ни вкладчиков, ни Центробанк РФ, ни мировое сообщество, поскольку клиентами также являлись и нерезиденты.

В этой связи ЦБ РФ провел глобальную работу по очистке системы банковских структур, помогло Центробанку в этом внесение изменений в законодательство - ЦБ РФ смог принимать непосредственное участие в ликвидационной процедуре кредитных структур, но в то же время функции контроля ЦБ РФ по ликвидации банковских организаций были лишь косвенными.

Существует проблема и в полномочиях ЦБ РФ по вопросу отзыва лицензий кредитных организаций. Согласно Ф3-395 «О банках и банковской деятельности» Центральный банк может отзывать лицензии у кредитных организаций в случае неоднократного нарушения 359 Федерального закона, данный факт вызывает вопросы у специалистов в банковской отрасли. Таким образом ЦБ РФ достаточно часто применяет санкции в отношении кредитных организаций за нарушение 115-Ф3 «О противодействии легализации (отмыванию) доходов, полученных преступным путем, и финансированию терроризма», что создает резонанс, поскольку указанная форма очень активно применяется и лицензии банков отзываются Центробанком на основании Ф3-395 «О банках и банковской деятельности».

В настоящее время в полномочия ЦБ РФ дополнены цели деятельности органа, куда входят: обеспечение устойчивости рубля и его защита, укрепление банковской системы РФ и её развитие, обеспечение стабильности национальной платёжной системы и её развития, а также новая цель - обеспечение стабильности финансового рынка РФ и его развития [2].

Для достижения целей Центральный Банк РФ дополнительно получил новые функции, а именно:

- создание и осуществление совместно с 
Правительством РФ политики обеспечения стабильности деятельности финансового рынка РФ и его развития;

- реализация регулирования за работой некредитных финансовых организаций, а также их контроль и надзор;

- проведение регистрации изготовления проспектов ценных бумаг и эмиссионных ценных бумаг;

- оформление отчётов об итогах выпусков эмиссионных ценных бумаг;

- реализация надзора и контроля за выполнением эмитентами требований законодательства РФ о ценных бумагах и акционерных обществах;

- реализация регулирования в сегменте корпоративных отношений в акционерных обществах, а также их надзор и контроль.

Ввиду передачи вышеуказанных полномочий специалисты считают, что цели и задачи Центрального Банка РФ весьма нечёткие и раз- мытые, а это влияет на правовые и экономические проблемы, которые связаны с независимостью Банка России. Тем не менее, Центробанк обязан согласовывать многочисленные вопросы с Правительством РФ, а в случае дополнения перечня целей ЦБ РФ происходит конфликт интересов, противоречие целей, а также риски для независимости Центрального Банка как финансового регулятора.

Подводя итог, можно сказать, что в настоящий момент имеется достаточное количество проблем, которые связаны с реализацией Центральным Банком Российской Федерации полномочий по надзору и контролю за работой членов рынка финансовых услуг. Эти проблемы требуют должного внимания, поскольку главным условием для эффективного управления правоотношениями на финансовом рынке является рациональное использование контрольных и надзорных функций Банка России.

\section{Библиографический список}

1. Меркулова И.В., Газарян Ю.А. Сущность банковского надзора и административной ответственности кредитных организаций на рынке банковских услуг // Аллея науки. - 2019. - 4 (31). С. 262-269.

2. Федеральный закон «О банках и банковской деятельности» от 02.12.1990 № 395-1 // Ведомости съезда народных депутатов РСФСР от 06 декабря 1990 г. № 27. Ст. 357.

3. Отчет о развитии банковского сектора и банковского надзора // Центральный банк Российской Федерации. URL: https://cbr.ru/publ/nadzor/.

4. Сведения о количестве действующих кредитных организаций и их филиалов в территориальном разрезе // Центральный банк Российской Федерации. URL: http://www.cbr.ru/statistics/? PrtId=lic

5. Сергин А.М. Банковский надзор и устойчивость кредитных организаций: проблемы действующей системы // Вестник Омского университета. Сер. Экономика. -2015. - № 2.- С. 55-65.

6. Юсупова М.Г. Надзор и контроль за банковской деятельностью в современных условиях // УЭПС: управление, экономика, политика, социология. - 2017. - № 3. С. 34-42. 